\title{
Analysis, Occurrence and Ecological Risk Assessment of Diclofenac and Ibuprofen Residues in Wastewater from Three Wastewater Treatment Plants in South-Western Nigeria
}

\author{
*11AJIBOLA, AS; ${ }^{1}$ ADEBIYI, AO; ${ }^{1}$ NWAEKE, DO; ${ }^{2} \mathrm{AJIBOLA,} \mathrm{FO;}{ }^{1} \mathrm{ADEWUYI}, \mathrm{GO}$ \\ ${ }^{*}$ Analytical/Environmental Unit, Department of Chemistry, University of Ibadan, Ibadan, Nigeria \\ ${ }^{2}$ Department of Crop Protection and Environmental Biology (Ecotoxicology), University of Ibadan, Ibadan, Nigeria \\ "Corresponding Author Email: akinrantiaji@ gmail.com
}

\begin{abstract}
Despite the frequent detection of non-steroidal anti-inflammatory drugs (NSAIDs) worldwide in the aquatic environment, there is currently a paucity of studies from Africa, including Nigeria, on the occurrence and potential ecological risks of two commonly used NSAIDs diclofenac and ibuprofen in wastewater and effluent receiving water. In this work, diclofenac and ibuprofen were determined in wastewater from three wastewater treatment plants (WWTPs) and effluent receiving water in South-Western Nigeria. Instrumental analysis was performed by high-performance liquid chromatography. Ecological risk was assessed for four trophic levels: fish, daphnia, algae and bacteria. The method quality parameters were satisfactory for the accurate determination of target NSAIDs in wastewater and effluent receiving water. Maximum concentrations of diclofenac and ibuprofen in wastewater were $166.1 \mu \mathrm{g} \mathrm{L}^{-1}$ (UCH influent) and $62.0 \mu \mathrm{g} \mathrm{L}^{-1}$ (Ijaiye effluent), respectively. Ibuprofen posed high risk to fish in all effluent and effluent receiving water samples. Bacteria were the most sensitive organisms to the presence of diclofenac while fish was the most sensitive to ibuprofen. To the best of our knowledge, this is the first report on the occurrence and ecological risk assessment of diclofenac and ibuprofen residues in wastewater from Nigerian municipal and hospital WWTPs. More efficient wastewater treatment processes and technologies are recommended for the investigated WWTPs to reduce the discharge of target NSAIDs and other pharmaceuticals into the Nigerian aquatic environment.
\end{abstract}

\section{DOI: https://dx.doi.org/10.4314/jasem.v25i3.5}

Copyright: Copyright $\left({ }^{\circ} 2021\right.$ Ajibola et al. This is an open access article distributed under the Creative Commons Attribution License (CCL), which permits unrestricted use, distribution, and reproduction in any medium, provided the original work is properly cited.

Dates: Received: 12 December 2020; Revised: 26 January 2021; Accepted: 12 February 2021

Keywords: Non-steroidal anti-inflammatory drugs, wastewater, ecological risk assessment, Nigeria

Pharmaceuticals are a class of emerging contaminants used extensively in human and veterinary medicine. Non-steroidal anti-inflammatory drugs (NSAIDs) diclofenac and ibuprofen are among the most common pain relief medications in the world (Zhang et al. 2020). Diclofenac and ibuprofen are the most commonly detected anti-inflammatory and analgesics in the environment due to their large consumption in daily life (Świacka et al. 2021; Zhang et al. 2020; Sui et al. 2015). Diclofenac was included in the watch list of substances to be established alongside the list of priority substances by the European Union (EU 2013; Vieno and Sillanpää 2014). Pharmaceutical compounds are not removed completely by conventional wastewater treatment technology (Verlicchi et al. 2012). Therefore, wastewater treatment plants (WWTPs) can contribute to the spread of diclofenac and ibuprofen residues in the environment through effluent discharges. Diclofenac and ibuprofen can also find their way into the environment through the disposal of unused or expired medicines (Thalla and Vannarath 2020). Consequently, due to their large consumption and incomplete removal in WWTPs, these NSAIDs have been detected worldwide in wastewater, surface water and groundwater (Sui et al. 2015; Luo et al. 2014). NSAIDs have been observed to present toxic effects on different group of aquatic organisms even at low, environmentally-relevant concentrations (Świacka $e t$ al. 2021). A study suggested that ibuprofen is embryotoxic to zebrafish embryos at a dose level of $>10 \mu \mathrm{g} / \mathrm{L}$ causing retarded development, decrease hatching rate and cardiac anomalies (David and Pancharatna 2009). A short term exposure of diclofenac and ibuprofen and their mixture to fish were also observed to induce various cytotoxic and genotoxic effects in Cyprinus caprio (Islas-Flores et al. 2017; Świacka et al. 2021). Moreover, the target NSAIDs were also recently found to impair the cardiovascular development of zebrafish (Danio rerio) at low environmentally relevant concentrations (Zhang et al. 2020). It is therefore important to assess the potential environmental risks posed by these NSAIDs to the aquatic organisms through the discharge of effluents from WWTPs into 
the aquatic environment. Ibuprofen is an over-thecounter drug in Nigeria and both NSAIDs are commonly prescribed. Consequently, there is high level of human consumption of these drugs and their occurrence is anticipated in wastewater from WWTPs and effluent receiving water (Ajibola et al. 2021). Moreover, studies on the analysis, occurrence and ecological risk assessment of diclofenac and ibuprofen are still limited in Africa. To our knowledge, there is no published study till date on the occurrence and ecological risk of diclofenac and ibuprofen in wastewater from Nigerian municipal and hospital WWTPs. These NSAIDs were quantified only in Nigerian surface water impacted by wastewater (Olarinmoye et al. 2016). Therefore, it is imperative to investigate the analysis and occurrence of diclofenac and ibuprofen residues in wastewater from Nigerian WWTPs and effluent receiving water, with a view to assessing the potential ecological risks associated with the discharge of wastewater into the Nigerian aquatic environment. This present study was, therefore, aimed at investigating the analysis, occurrence and potential ecological risks of diclofenac and ibuprofen in wastewater from three WWTPs and effluent receiving water in South-Western Nigeria. First report is provided on the occurrence and potential ecological risks of diclofenac and ibuprofen residues in wastewater from municipal and hospital WWTPs, and effluent receiving water in South-Western Nigeria.

\section{MATERIALS AND METHODS}

Chemicals and reagents: Diclofenac and ibuprofen analytical standards were purchased from Sigma Aldrich (Steinheim, Germany). HPLC grade acetonitrile was obtained from Merck (Darmstadt, Germany). Ultrapure water was provided by a Milli-Q water purification system (Merck, Germany). Chloroform was obtained from Chemicals BDH Ltd. (Poole, England). Formic acid of analytical grade was used. MF-Millipore membrane filters (mixed cellulose esters) of $0.45 \mu \mathrm{m}$ pore size were obtained from Merck (Darmstadt, Germany). Stock standard solutions (100 $\mu \mathrm{g} \mathrm{mL}^{-1}$ ) of diclofenac and ibuprofen were prepared in acetonitrile. Standard working solutions for sample spiking were prepared from the stock solutions.

Sample collection and pretreatment: Wastewater samples (influent and effluent) were collected from three wastewater treatment plants (WWTPs) in Lagos and Ibadan, South-Western Nigeria: Alausa WWTP in Lagos, Ijaiye WWTP in Lagos and University College Hospital (UCH) WWTP in Ibadan. Alausa WWTP is an urban municipal wastewater treatment plant. Ijaiye and UCH WWTPs are hospital wastewater treatment plants. UCH and Alausa WWTPs employ the activated sludge process of treatment while Ijaiye WWTP uses a membrane bioreactor with anaerobic digestion as treatment processes. The characteristics and operational parameters of the investigated wastewater treatment plants have been presented in previous studies (Ajibola et al. 2020a; Ajibola et al. 2021). Maps of the locations of the investigated WWTPs are shown in Fig 1. Effluent receiving water samples were collected from Dandaru river (the receiving water body of UCH effluents), which flows through the Agodi gardens. Water samples were also collected from drainage at Ijaiye WWTP through which effluents are discharged into the environment.

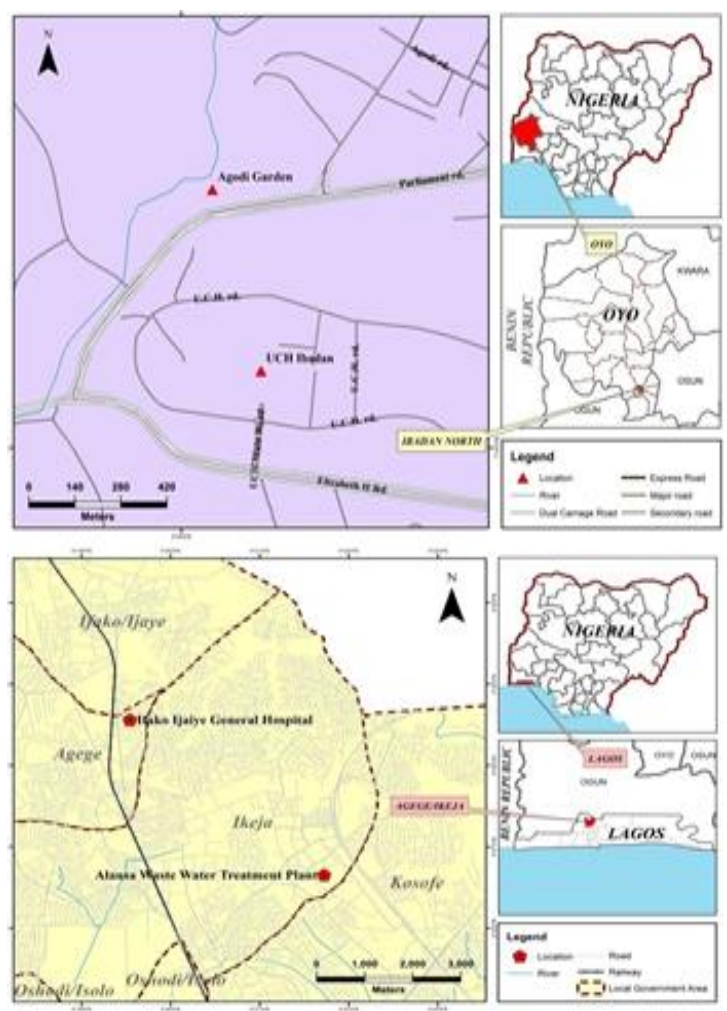

Fig. 1: Maps of locations of the investigated wastewater treatment plants

Pre-cleaned amber glass bottles were used for samples collection. Wastewater samples and effluent receiving water samples were collected from the three WWTPs in July 2017. The samples were transported immediately into the laboratory in an insulated box (cooler) with ice. The samples were stored in the freezer at $4{ }^{\circ} \mathrm{C}$ before extraction. All wastewater and effluent receiving water samples were extracted within 48 hours. Wastewater samples were filtered through $0.45 \mu \mathrm{m}$ membrane filters prior to extraction.

Extraction of wastewater samples: Extraction of wastewater was carried out using liquid-liquid extraction, adopting the method of Ashfaq et al. 2017a with slight modifications. Briefly, $50 \mathrm{~mL}$ of 
wastewater sample was extracted using $20 \mathrm{~mL}$ chloroform in three different successive extractions (60 $\mathrm{mL}$ total volume) in a separatory funnel. The mixture of wastewater sample and chloroform was shaken for ten minutes and then allowed to stand for separation of the organic and aqueous layers. The organic layer was collected and gently evaporated to dryness at $38^{\circ} \mathrm{C}$. The residue was reconstituted in $2 \mathrm{~mL}$ of a mixture of acetonitrile and acidified water $(\mathrm{pH}$ of 3.0), 85:15 (v/v) and transferred into a $2 \mathrm{~mL}$ vial for chromatographic analysis.

HPLC Analysis: Separation and detection of target compounds were performed using an Agilent Series 1100 HPLC system equipped with UV and fluorescence detectors. The HPLC system was equipped with an Agilent degasser, a pump and an auto-sampler. Separation and detection of compounds were carried out according to Ajibola et al. 2021. Briefly, separation of the analytes was achieved with a Zorbax Eclipse XDB-C18 column (4.6 mm x 150 $\mathrm{mm}, 5 \mu \mathrm{m})$ at ambient temperature. Mobile phase consisted of acetonitrile and ultrapure water (acidified to $\mathrm{pH} 3.0$ with formic acid), 60:40 (v/v). Isocratic elution was carried out at a flow rate of $0.8 \mathrm{~mL} \mathrm{~min}^{-1}$. Three minutes of re-equilibration was programmed between successive injections and the injection volume was $20 \mu \mathrm{L}$. The wavelength of $230 \mathrm{~nm}$ was used for UV detection. The excitation wavelength and emission wavelength for fluorescence detection (FLD) were $230 \mathrm{~nm}$ and $302 \mathrm{~nm}$, respectively. Only ibuprofen could be detected with the applied FLD excitation and emission wavelengths. Every chromatographic run was carried out with both UV and Fluorescence detectors simultaneously. UV detection was selected for quantitation of both diclofenac and ibuprofen as it allowed the detection of both compounds. However, fluorescence detection was used for confirmation of the presence and identification of ibuprofen by matching its retention times in the chromatograms of both UV detection and fluorescence detection. The analytes were identified in the chromatograms by comparing the retention time of the peaks in the sample solution to the corresponding peaks in the standard solutions. Quantification of target compounds was carried out using the matrix-matched calibration curves constructed by spiking matrix extracts after the extraction. The chromatograms of diclofenac and ibuprofen for standard solution $\left(10 \mu \mathrm{g} \mathrm{mL} \mathrm{mL}^{-1}\right)$ are shown in Fig. 2.

Quality assurance and method quality parameters: Analyses of procedural blanks were carried out to ensure that the reagents used were free of the analytes of interest. In order to ascertain if the HPLC mobile phase was free of diclofenac and ibuprofen residues, $20 \mu \mathrm{L}$ of the mobile phase (acetonitrile/acidified water) was injected into the HPLC instrument. The procedural blanks and mobile phase contained no ibuprofen and diclofenac residues since no peak was observed for the two compounds at their respective retention times.
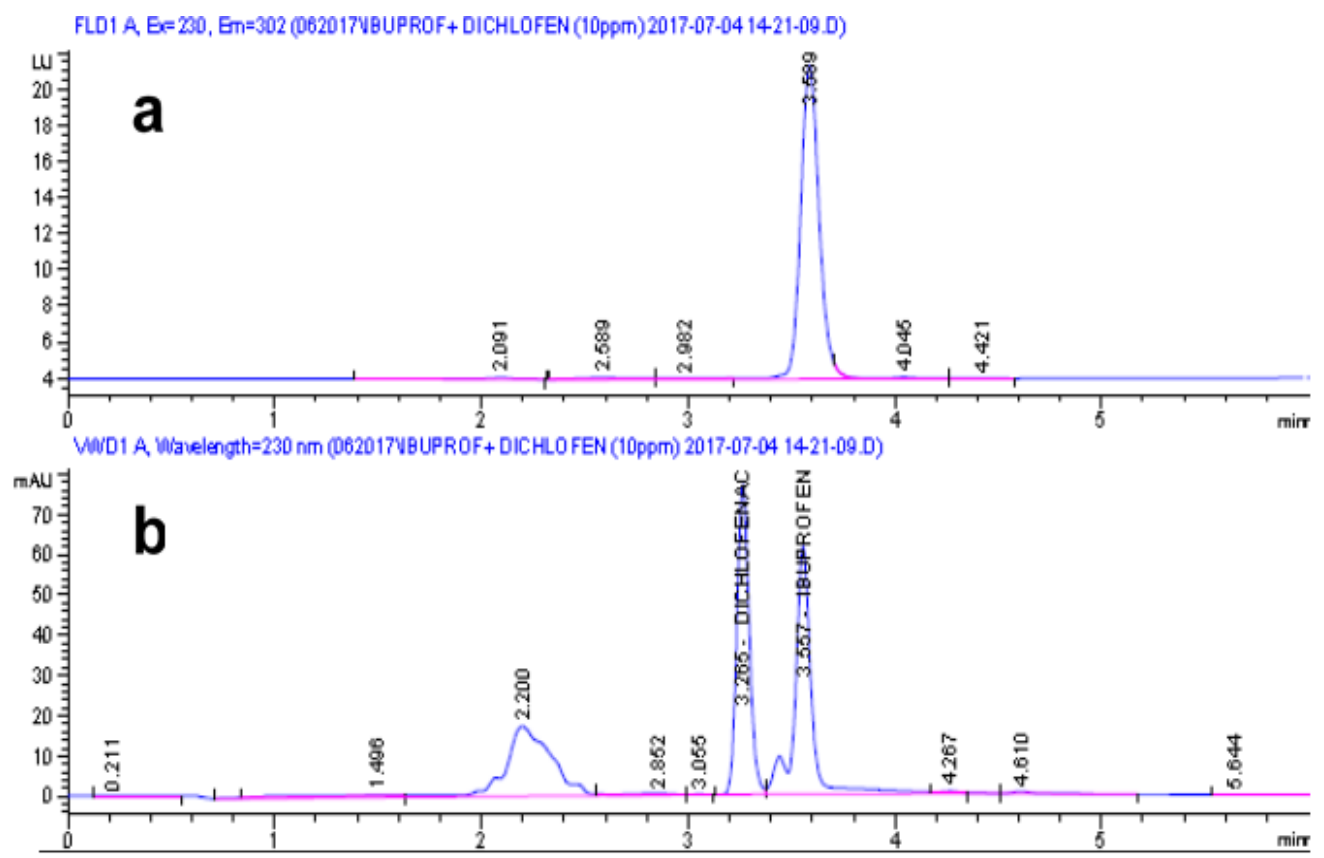

Fig. 2: Chromatograms of diclofenac and ibuprofen standard solution $\left(10 \mu \mathrm{g} \mathrm{mL}^{-1}\right)$; (a) Fluorescence detection (FLD), (b) Ultraviolet (UV) detection 
Between successive injections of samples into the HPLC instrument, solvent blank (consisting of only mobile phase) injections were carried out to avoid carry over from a previous injection. Linearity was assessed by generating matrix-matched calibration curves at concentration range of $0.1 \mu \mathrm{g} \mathrm{mL}-1-5.0 \mu \mathrm{g}$ $\mathrm{mL}^{-1}$. Matrix matched calibration curve was generated by spiking wastewater samples after extraction. The generated calibration curves were used for the quantification of ibuprofen and diclofenac. Recoveries were determined by spiking wastewater samples before extraction at $0.5 \mu \mathrm{g} \mathrm{mL} \mathrm{L}^{-1}$ (corresponding concentration in final extract). Response obtained for spiked sample was compared with that of standard solution of compound in pure solvent. Precision of the method for wastewater analysis was assessed by performing intra-day analysis. Wastewater extracts were spiked at $0.5 \mu \mathrm{g} \mathrm{mL} \mathrm{m}^{-1}$ and five replicate determinations were carried out. The intra-day precision (repeatability) was expressed as relative standard deviation (RSD, \%). Limit of detection (LOD) and limit of quantification (LOQ) for wastewater analysis were determined by spiking wastewater extract at $0.5 \mu \mathrm{g} \mathrm{mL}^{-1}$. Five replicate determinations were carried out. The method LOD was calculated by multiplying the standard deviation of responses of the replicate determinations by a factor of 3.3 divided by the slope of the calibration curve. LOQ was also calculated by multiplying the standard deviation of the responses of replicate determinations with a factor 10 divided by the slope of the calibration curve.

Ecological risk assessment: Risk assessment of ibuprofen and diclofenac residues in effluent and effluent receiving water was evaluated by calculating risk quotient (RQ) value as the ratio of measured environmental concentrations (MEC) to the predicted no effect concentrations (PNEC) of the target pharmaceuticals (European Commission 2003). Maximum concentration was used as MEC for calculating RQ value to assess the worst case scenario. In cases where all the measured concentrations were below the LOQ, LOQ value of each pharmaceutical was used as MEC for the RQ calculation. PNEC for wastewater and effluent receiving water $\left(\mathrm{PNEC}_{\text {water }}\right)$ was calculated by dividing $\mathrm{EC}_{50}$ by an assessment factor of 1000 (Martin et al. 2012). Toxicity data $\left(\mathrm{EC}_{50}\right)$ was obtained from literature for four different trophic levels: fish, daphnia, algae and bacteria (Verlicchi et al. 2012; Sanderson et al. 2003; Ra et al. 2008). The toxicity data of the target NDAIDs and literature sources are shown in Table 1. The risk ratio categories according to Wee et al. 2019 were adopted: negligible risk $(\mathrm{RQ}<0.01)$, low risk $(0.01 \leq \mathrm{RQ}<0.1)$, medium risk $(0.1 \leq \mathrm{RQ}<1)$, and high risk $(\mathrm{RQ} \geq 1)$.

Table 1 Toxicity data of diclofenac and ibuprofen

\begin{tabular}{|c|c|c|c|c|c|c|c|c|}
\hline \multirow{2}{*}{$\begin{array}{l}\text { Compound } \\
\text { Organism }\end{array}$} & \multicolumn{4}{|c|}{ Diclofenac } & \multicolumn{4}{|l|}{ Ibuprofen } \\
\hline & Fish & Daphnia & Algae & Bacteria & Fish & Daphnia & Algae & Bacteria \\
\hline Test & $\mathrm{EC}_{50}$ & $\mathrm{EC}_{50}$ & $\mathrm{EC}_{50}$ & $\mathrm{EC}_{50}$ & $\mathrm{EC}_{50}$ & $\frac{1}{\mathrm{EC}_{50}}$ & $\mathrm{EC}_{50}$ & $\mathrm{EC}_{50}$ \\
\hline (end point) & ECOSAR & ECOSAR & ECOSAR & $\begin{array}{l}\text { (15 min } \\
\text { inhibition) }\end{array}$ & ECOSAR & ECOSAR & ECOSAR & $\begin{array}{l}\text { (15 min } \\
\text { inhibition) }\end{array}$ \\
\hline $\begin{array}{l}\text { Toxicity } \\
\left(\mathrm{mg} \mathrm{L}^{-1}\right)\end{array}$ & 532 & 5057 & 2911 & 9.7 & 5 & 38 & 26 & 37.5 \\
\hline $\begin{array}{l}\text { PNEC } \\
\left(\mu \mathrm{g} \mathrm{L}^{-1}\right)\end{array}$ & 532 & 5057 & 2911 & 9.7 & 5 & 38 & 26 & 37.5 \\
\hline References & \multicolumn{3}{|c|}{$\begin{array}{l}\text { Verlicchi et al. 2012, } \\
\text { Sanderson } \text { et al. } 2003\end{array}$} & $\begin{array}{l}\text { Ra et al. } 2008, \\
\text { Verlicchi et al. } \\
2012\end{array}$ & \multicolumn{3}{|c|}{$\begin{array}{l}\text { Verlicchi et al. 2012, } \\
\text { Sanderson } \text { et al. } 2003\end{array}$} & $\begin{array}{l}\text { Ra et al. } \\
2008, \text { Verlicchi } \\
\text { et al. } 2012\end{array}$ \\
\hline
\end{tabular}

Table 2: Method performance parameters

\begin{tabular}{llllll}
\hline Compound & $\begin{array}{l}\text { Recovery (\%) } \\
(0.5 \mu \mathrm{g} \mathrm{mL} \\
\text { fortification) }\end{array}$ & $\begin{array}{l}\text { Intra-day RSD } \\
(\%),\end{array}$ & $\begin{array}{l}\mathrm{LOD} \\
\left.(\mu \mathrm{g} \mathrm{L})^{-1}\right)\end{array}$ & $\begin{array}{l}\mathrm{LOQ} \\
\left(\mu \mathrm{g} \mathrm{L}^{-1}\right)\end{array}$ & $\mathrm{r}^{2}$ \\
\hline $\begin{array}{l}\text { Diclofenac } \\
\text { Ibuprofen }\end{array}$ & $\begin{array}{l}103 \pm 4 \\
45 \pm 30\end{array}$ & 3.2 & 1.6 & 4.9 & 0.9993 \\
\hline
\end{tabular}

\section{RESULTS AND DISCUSSION}

Analytical performance parameters: The method performance parameters in wastewater are presented in Table 2. The correlation coefficients of matrixmatched calibration curves for diclofenac and ibuprofen were 0.9993 and 0.9990 , respectively. The method LOD and LOQ for diclofenac were $1.6 \mu \mathrm{g} \mathrm{L}^{-1}$ and $4.9 \mu \mathrm{g} \mathrm{L}^{-1}$, respectively while the method LOD and
LOQ of ibuprofen were 7.5 and $22.8 \mu \mathrm{g} \mathrm{L} \mathrm{L}^{-1}$, respectively. Similar LOQ values were reported for diclofenac and ibuprofen in previously reported studies (Ashfaq et al. 2017a, b; Aguilar-Arteaga et al. 2010). It should be emphasized that we used ultraviolet (UV) detector instead of the more sensitive but expensive mass spectrometric detector which are not readily available in most laboratories of 
developing countries. The recovery of diclofenac was $103 \%$ while that of ibuprofen was $45 \%$. Due to the achieved relatively lower recovery of ibuprofen than that of diclofenac, matrix-matched calibration was applied for the quantification of both NSAIDs. Satisfactory intra-day precision (\% RSD) values of $3.2 \%$ and $14.3 \%$ were obtained for diclofenac and ibuprofen respectively.

Occurrence of diclofenac and ibuprofen in wastewater and effluent receiving water: Wastewater (influent and effluent) and effluent receiving water collected from three Nigerian WWTPs were analyzed for the presence of target compounds. The results of the concentration profiles in wastewater (influent and effluent) and effluent receiving water are presented in Table 3. Diclofenac and ibuprofen were detected in all the wastewater (influent and effluent) and effluent receiving water samples, though at levels below the limits of quantification in few samples. The highest concentration of diclofenac was quantified in the influent from UCH WWTP $\left(166 \mu \mathrm{g} \mathrm{L}^{-1}\right)$. However, the highest concentration of ibuprofen in influent $(45 \mu \mathrm{g}$ $\mathrm{L}^{-1}$ ) was detected in Alausa WWTP which is a municipal WWTP. Ibuprofen was measured in UCH influent and Ijaiye influent at $32 \mu \mathrm{g} \mathrm{L}^{-1}$ and $36 \mu \mathrm{g} \mathrm{L}^{-1}$, respectively. This indicates that during the period of sampling the consumption rate of ibuprofen by the Alausa residents was higher than the dispensing rate by UCH or Ijaiye hospital. Concentration of ibuprofen in effluent ranged from <LOQ (for UCH WWTP) to $62 \mu \mathrm{g} \mathrm{L}^{-1}$ (for Ijaiye WWTP) whereas diclofenac in effluent ranged from $<$ LOQ (for Alausa WWTP) to $37 \mu \mathrm{g} \mathrm{L}^{-1}$ (for UCH WWTP). The concentration of ibuprofen was higher in effluent than in influent at Ijaiye WWTP. A plausible explanation could be the formation of ibuprofen conjugated metabolites during wastewater treatment and capability of the ibuprofen conjugated metabolites to transform back to ibuprofen (Nurmi et al. 2019). This deconjugation of ibuprofen metabolites could contribute to an increase in ibuprofen concentration in effluent. Concentration of diclofenac in influent from UCH WWTP, Ijaiye WWTP and Alausa WWTP were $166 \mu \mathrm{g} \mathrm{L}^{-1}, 39 \mu \mathrm{g} \mathrm{L}$ ${ }^{1}$ and $48 \mu \mathrm{g} \mathrm{L}^{-1}$, respectively. Higher concentration of diclofenac in UCH influent than Ijaiye influent implies that diclofenac was prescribed and dispensed to patients at higher rate in $\mathrm{UCH}$ than in Ijaiye hospital. This was not unexpected as $\mathrm{UCH}$ is a tertiary health facility which admits and treats higher number of patients than Ijaiye hospital which is a secondary health facility. Measured concentrations of diclofenac (41 $\left.\mu \mathrm{g} \mathrm{L}^{-1}\right)$ and ibuprofen $\left(60 \mu \mathrm{g} \mathrm{L}^{-1}\right)$ in Dandaru river (UCH effluent receiving water) were higher than the corresponding concentrations in $\mathrm{UCH}$ effluent $(37 \mu \mathrm{g}$ $\mathrm{L}^{-1}$ for diclofenac and <LOQ for ibuprofen). Dandaru
River flows through the Agodi gardens which is a recreational environment for tourists (Ajibola et al. $2020 b$ ). Therefore, the higher concentrations of both compounds in Dandaru River than in UCH effluent could be attributed to contributions from other emission sources such as disposal of unused and expired drugs into the river. Concentration of up to 62 $\mu \mathrm{g} \mathrm{L}^{-1}$ was also measured in South Africa by Matongo et al. 2015 for ibuprofen in river water. Ijaiye drainage $\mathrm{w}$ ater (Ijaiye effluent receiving water) had lower concentrations of both diclofenac (<LOQ) and ibuprofen $\left(44 \mu \mathrm{g} \mathrm{L}^{-1}\right)$ than in Ijaiye effluent. This suggests that effluent dilution probably occurred as effluent was discharged from the WWTP. In this study, the concentration levels of diclofenac and ibuprofen in wastewater were higher than detected amounts in Europe and North America (Verlicchi et al. 2012; Samaras et al. 2010; Patrolecco et al. 2013; Martin et al. 2012). However, the occurrence in Europe and North America at lower concentrations than in this study cannot be generalized because some studies (Lonappan et al. 2016; Guerra et al. 2014; Huber et al. 2016) in Europe and North America reported much higher concentrations comparable to the levels detected in this study. The higher levels of these compounds in influent samples indicate high level consumption and administration of these drugs at both UCH and Ifako-ijaiye hospital. In comparison with this study, similar concentration levels of diclofenac and ibuprofen were reported in influent and effluent of WWTPs in South Africa, Kenya and Tunisia (Madikizela et al. 2017; Amdany et al. 2014; K'oreje et al. 2012; Khazri et al. 2019), suggesting possible similar consumption patterns in Africa. However, relatively higher concentrations of diclofenac and ibuprofen were quantified in wastewater in the Indian subcontinent, up to $2109.8 \mu \mathrm{g} \mathrm{L}^{-1}$ of ibuprofen in influent (Thalla and Vannarath 2020; Ashfaq et al. 2017a, b; Hanif et al. 2020).

Ecological risk assessment: The risk quotient (RQ) values of diclofenac and ibuprofen in wastewater effluent and effluent receiving water are presented in Fig. 3. Diclofenac posed low risks to algae and fish in $\mathrm{UCH}$ effluent and Dandaru river (UCH effluent receiving water) while negligible risk was posed to algae in Ijaiye effluent, Ijaiye drainage water and Alausa effluent. Also, diclofenac posed low risk to fish in Ijaiye effluent whereas negligible risk was presented to fish in Ijaiye drainage water and Alausa effluent. Thalla and Vannarath (2020) recently obtained RQ values of below 0.1 in treated wastewater (effluent) for diclofenac and ibuprofen, which showed low risk to fish and algae. Diclofenac in all effluent and effluent receiving water samples posed negligible risk to daphnia. 
Table 3: Concentrations of diclofenac and ibuprofen residues in wastewater from three Nigerian WWTPs and effluent receiving water

\begin{tabular}{|c|c|c|c|c|c|c|c|c|}
\hline \multirow[b]{2}{*}{ Compound } & \multicolumn{3}{|c|}{ UCH WWTP } & \multicolumn{3}{|c|}{ Ijaiye WWTP } & \multicolumn{2}{|c|}{ Alausa WWTP } \\
\hline & $\begin{array}{l}\text { Wastewater } \\
\text { Influent }\end{array}$ & $\begin{array}{l}\text { Wastewater } \\
\text { Effluent }\end{array}$ & $\begin{array}{l}\text { Dandaru } \\
\text { river }\end{array}$ & $\begin{array}{l}\text { Wastewater } \\
\text { Influent }\end{array}$ & $\begin{array}{l}\text { Wastewater } \\
\text { Effluent }\end{array}$ & $\begin{array}{l}\text { Ijaiye } \\
\text { drainage water }\end{array}$ & $\begin{array}{l}\text { Wastewater } \\
\text { Influent }\end{array}$ & $\begin{array}{l}\text { Wastewater } \\
\text { Effluent }\end{array}$ \\
\hline Diclofenac & $166 \pm 5$ & $37 \pm 2$ & $41 \pm 2$ & $39 \pm 1$ & $21 \pm 1$ & $<\mathrm{LOQ}$ & $48 \pm 2$ & $<\mathrm{LOQ}$ \\
\hline Ibuprofen & $32 \pm 5$ & $<\mathrm{LOQ}$ & $60 \pm 9$ & $36 \pm 5$ & $62 \pm 9$ & $44 \pm 6$ & $45 \pm 6$ & $32 \pm 5$ \\
\hline
\end{tabular}

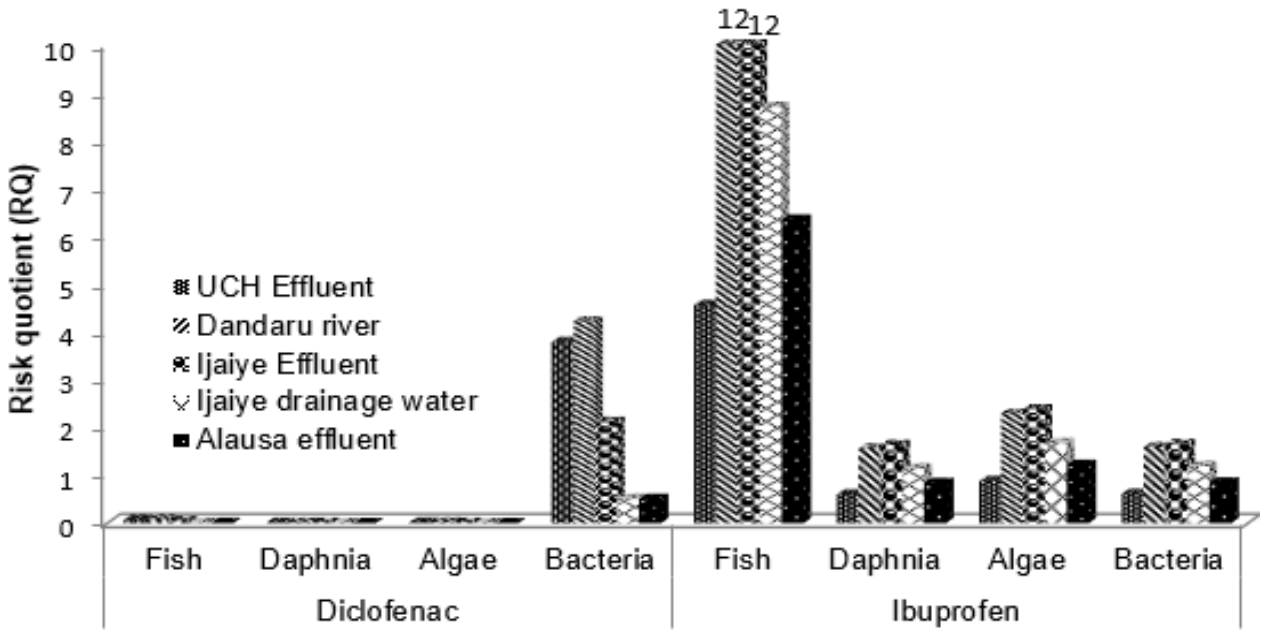

Fig. 3: Risk quotient values of diclofenac and ibuprofen in wastewater effluent and effluent receiving water

In a recent study by Hanif et al. (2020) RQ values of diclofenac for Daphnia magna in wastewater and surface water were very low (less than 0.01 ), indicating negligible risks to this aquatic species which is in agreement with this present study. Diclofenac presented high risk to bacteria in $\mathrm{UCH}$ effluent, Dandaru river and Ijaiye effluent while medium risk was presented to bacteria by Ijaiye drainage water and Alausa effluent. Moreover, ibuprofen in all effluent and effluent receiving water samples posed high risk to fish and algae, except for $\mathrm{UCH}$ effluent which presented medium risk to algae. Although ibuprofen in UCH effluent and Alausa effluent posed medium risks to daphnia and bacteria, its presence in Dandaru river, Ijaiye effluent and Ijaiye drainage water posed high risk to daphnia and bacteria. In a French national water survey on the ecological risk assessment of the presence of pharmaceutical residues, ibuprofen was identified as posing real environmental risk to O. latipes based on its MEC (RQ = 1.9) (Bouissou-Schurtz et al. 2014). Ibuprofen was also found to pose high risk in secondary biological effluent in a study by Verlicchi et al. 2012. Ashfaq and coworkers also assessed ibuprofen against fish, green algae and $O$. latipes and found RQ values to be as high as 1013,253 and 167,300 respectively against the investigated species (Ashfaq et al. 2017b). These high RQ values in their study indicated that ibuprofen could pose high level of risk to the assessed organisms. Overall, in this present study bacteria were the most sensitive organisms to the presence of diclofenac while fish was the most sensitive to the presence of ibuprofen.

Conclusions: Diclofenac and ibuprofen residues were determined in wastewater and effluent receiving water from three WWTPs in South-Western Nigeria. Potential ecological risks of target compounds were assessed. Diclofenac was quantified up to $166 \mu \mathrm{g} \mathrm{L} \mathrm{L}^{-1}$ while the highest measured concentration of ibuprofen was $62 \mu \mathrm{g} \mathrm{L}^{-1}$. Ibuprofen posed high risk to fish in all effluent and effluent receiving water. The high RQ values of ibuprofen indicate serious threats to the aquatic ecosystem, especially fish. More efficient wastewater treatment processes and technologies are, therefore, recommended for the investigated WWTPs to reduce the discharge of the target NSAIDs and other pharmaceuticals into the Nigerian aquatic environment.

Acknowledgements: Officials at the investigated wastewater treatment plants are acknowledged for assistance in the collection of wastewater samples.

\section{REFERENCES}

Aguilar-Arteaga, K; Rodriguez, JA; Miranda, JM; Medina, J; Barrado, E (2010). Determination of non-steroidal anti-inflammatory drugs in wastewaters by magnetic matrix solid phase dispersion-HPLC. Talanta 80: 1152-1157. 
Ajibola, AS; Tisler, S; Zwiener, C (2020a). Simultaneous determination of multiclass antibiotics in sewage sludge based on QuEChERS extraction and liquid chromatography-tandem mass spectrometry. Anal Methods 12: 576-586.

Ajibola, AS; Amoniyan, OA; Ekoja, FO; Ajibola, FO (2020b). QuEChERS Approach for the Analysis of Three Fluoroquinolone Antibiotics in Wastewater: Concentration Profiles and Ecological Risk in Two Nigerian Hospital Wastewater Treatment Plants. Arch. Environ. Contam. Toxicol. https://doi.org/10.1007/s00244-020-00789-w

Ajibola, AS; Fawole, ST; Ajibola, FO; Adewuyi, GO (2021). Diclofenac and ibuprofen determination in sewage sludge using a QuEChERS approach: Occurrence and ecological risk assessment in three Nigerian wastewater treatment plants. Bull. Environ. Contam. Toxicol. https://doi.org/10.1007/s00128-021-03139-1

Amdany, R; Chimuka, L; Cukrowska, E (2014). Determination of naproxen, ibuprofen, and triclosan in wastewater using the polar organic chemical integrative sampler (POCIS): A laboratory calibration and field application. Water SA 40(3): 407-414

Ashfaq, M; Noor, N; Saif Ur Rehman, M; Sun, Q; Mustafa, G; Nazar, MF; Yu, CP (2017a). Determination of commonly used pharmaceuticals in hospital waste of Pakistan and evaluation of their ecological risk assessment. CLEAN-Soil, Air, Water 45(6): 1500392.

Ashfaq, M; Khan, KN; Saif Ur Rehman, M; Mustafa, G; Nazar, MF; Sun, Q; Yu, CP (2017b). Ecological risk assessment of pharmaceuticals in the receiving environment of pharmaceutical wastewater in Pakistan. Ecotox. Environ. Saf. 136:31-39.

Bouissou-Schurtz, C; Houeto, P; Guerbet, M; Bachelot, M; Casellas, C; Mauclaire, AC; Panetier, P; Delval, C; Masset, D (2014). Ecological risk assessment of the presence of pharmaceutical residues in a French national water survey. Regul. Toxicol. Pharmacol. 69:296-303.

David, A; Pancharatna, K (2009). Developmental anomalies induced by a non-selective COX inhibitor (ibuprofen) in zebrafish (Danio rerio). Environ. Toxicol. Pharmacol. 27: 390-395.

EU (2013). Directive 2013/39/EU of the European Parliament and of the Council. Available in www format: URL: $\quad$ http://eurlex.europa.eu/LexUriServ/LexUriServ.do?uri=OJ: L:2013:226:0001:0017:EN:PDF

European Commission (2003). Technical guidance document in support of commission directive 93/67/EEC on risk assessment for new notified substances and commission regulation (EC) no 1488/94 on risk assessment for existing substances, part II, (Brussels, Belgium).

Guerra, P; Kim, M; Shah, A; Alaee, M; Smyth, SA (2014). Occurrence and fate of antibiotics, analgelsics/anti-inflammatory and antifungal compounds in wastewater treatment processes. Sci. Total Environ. 473-474: 235-243.

Hanif, H; Waseem, A; Kali, S; Qureshi, NA; Majid, M; Iqbal, M; Ur-Rehman, T; Tahir, M; Yousaf, S; Iqbal, MM; Khan, IA; Zafar, MI (2020). Environmental risk assessment of diclofenac residues in surface waters and wastewater: a hidden global threat to aquatic ecosystem. Environ. Monit. Assess. 192: 204.

Huber, S; Remberger, M; Kaj, L; Schlabach, M; Jörundsdóttir, HO; Vester, J; Arnórsson, M; Mortensen, I; Schwartson, R; Damj, M (2016). A first screening and risk assessment of pharmaceuticals and additives in personal care products in waste water, sludge, recipient water and sediment from Faroe Islands, Iceland and Greenland. Sci. Total Environ. 562: 13-25.

Islas-Flores, H; Gómez-Oliván, LM; Galar- Martínez, M; Sánchez-Ocampo, EM; SanJuan- Reyes, N; Ortíz- Reynoso, M; Dublán- Garcí, O (2017). Cyto-genotoxicity and oxidative stress in common carp (Cyprinus carpio) exposed to a mixture of ibuprofen and diclofenac. Environ. Toxicol. 32(5): 1637-1650.

Khazri H; Hassine, SB; Ghorbel-Abid, I; Kalfat, R; Trabelsi-Ayadi, M (2019). Presence of carbamazepine, naproxen, and ibuprofen in wastewater from northern Tunisia. Environ. Forensics 20: 121-128.

K'oreje, KO; Demeestere, K; De Wispelaere, P; Vergeynst, L; Dewulf, J; Van Langenhove, H (2012). From multi-residue screening to target analysis of pharmaceuticals in water: development of a new approach based on magnetic sector mass spectrometry and application in the Nairobi River basin, Kenya. Sci. Total Environ. 437: 153-164. 
Lonappan, L; Pulicharla, R; Rouissi, T; Brar, SK; Verma, M; Surampalli, RY; Valero, JR (2016). Diclofenac in municipal wastewater treatment plant: J. Chromatogr. A 1433: 106-113.

Luo, Y; Guo, W; Ngo, HH; Nghiem, LD; Hai, FI; Zhang, J; Liang, S (2014). A review on the occurrence of micropollutants in the aquatic environment and their fate and removal during wastewater treatment. Sci. Total Environ. 473474:619-641.

Madikizela, LM; Chimuka, L (2017). Occurrence of naproxen, ibuprofen, and diclofenac residues in wastewater and river water of KwaZulu-Natal Province in South Africa. . Environ. Monit. Assess. 189: 348 .

Martin, J; Camacho-Muñoz, D; Santos, JL; Aparicio, I; Alonso, E (2012). Occurrence of pharmaceutical compounds in wastewater and sludge from wastewater treatment plants: Removal and ecotoxicological impact of wastewater discharges and sludge disposal. J. Hazard. Mater. 239-240: 40-47.

Matongo, S; Birungi, G; Moodley, B; Ndungu, P (2015). Occurrence of selected pharmaceuticals in water and sediment of Umgeni River, KwaZuluNatal, South Africa. Environ. Sci. Pollut. Res. 22:10298-10308

Nurmi, TMA; Kiljunen, TK; Knuutinen, JS (2019). A fugacity model assessment of ibuprofen, diclofenac, carbamazepine, and their transformation product concentrations in an aquatic environment. Environ. Sci. Pollut. Res. 26:328-341.

Olarinmoye, O; Bakare, A; Ugwumba, O; Hein, A (2016). Quantification of pharmaceutical residues in wastewater impacted surface waters and sewage sludge from Lagos, Nigeria. J. Environ. Chem. Ecotox. 8: 14-24.

Patrolecco, L; Ademollo, N; Grenni, P; Tolomei, A; Caracciolo, AB; Capri, S (2013). Simultaneous determination of human pharmaceuticals in water samples by solid phase extraction and HPLC with UV-fluorescence detection. Microchem. J. 109: 165-171.

Ra, JS; Oh, SY; Lee, BC; Kim, SD (2008). The effect of suspended particles coated by humic acid on the toxicity of pharmaceuticals, estrogens, and phenolic compounds. Environ. Int. 34: 184-192.
Samaras, VG; Thomaidis, NS; Stasinakis, AS; Gatidou, G; Lekkas, TD (2010). Determination of selected non-steroidal anti-inflammatory drugs wastewater by gas chromatography-mass spectrometry. Int. J. Environ. Anal. Chem. 90: 219229.

Sanderson, H; Johnson, DJ; Wilson, CJ; Brain, RA; Solomon, KR (2003). Probabilistic hazard assessment of environmentally occurring pharmaceuticals toxicity to fish, daphnids and algae by ECOSAR screening. Toxicol. Lett. 144:383-395.

Sui, Q; Cao, X; Lu, S; Zhao, W; Qiu, Z; Yu, G (2015). Occurrence, sources and fate of pharmaceuticals and personal care products in the groundwater: A review. Emerging Contaminants 1: 14-24.

Świacka, K; Michnowska, A; Maculewicz, J; Caban, M; Smolarz, K (2021). Toxic effects of NSAIDs in non-target species: a review from the perspective of the aquatic environment. Environ. Pollut. 273: 115891.

Thalla, AR; Vannarath, AS (2020). Occurrence and environmental risks of nonsteroidal antiinflammatory drugs in urban wastewater in the southwest monsoon region of India. Environ. Monit. Assess. 192:193.

Verlicchi, P; Al Aukidy, M; Zambello, E (2012). Occurrence of pharmaceutical compounds in urban wastewater: removal, mass load and environmental risk after a secondary treatment - a review. Sci. Total Environ. 429:123-155.

Vieno, N; Sillanpää, M (2014). Fate of diclofenac in municipal wastewater treatment plant-A review. Environ. Int. 69: 28-39.

Wee, SY; Aris, AZ; Yusoff, FMd; Praveena, SM (2019). Occurrence and risk assessment of multiclass endocrine disrupting compounds in an urban tropical river and a proposed risk management and monitoring framework. Sci. Total Environ. 671:431-442.

Zhang, K; Yuan, G; Werdich, AA; Zhao, Y (2020). Ibuprofen and diclofenac impair the cardiovascular development of zebrafish (Danio rerio) at low concentrations. Environ. Pollut. 258: 113613. 